Provided for non-commercial research and education use. Not for reproduction, distribution or commercial use.

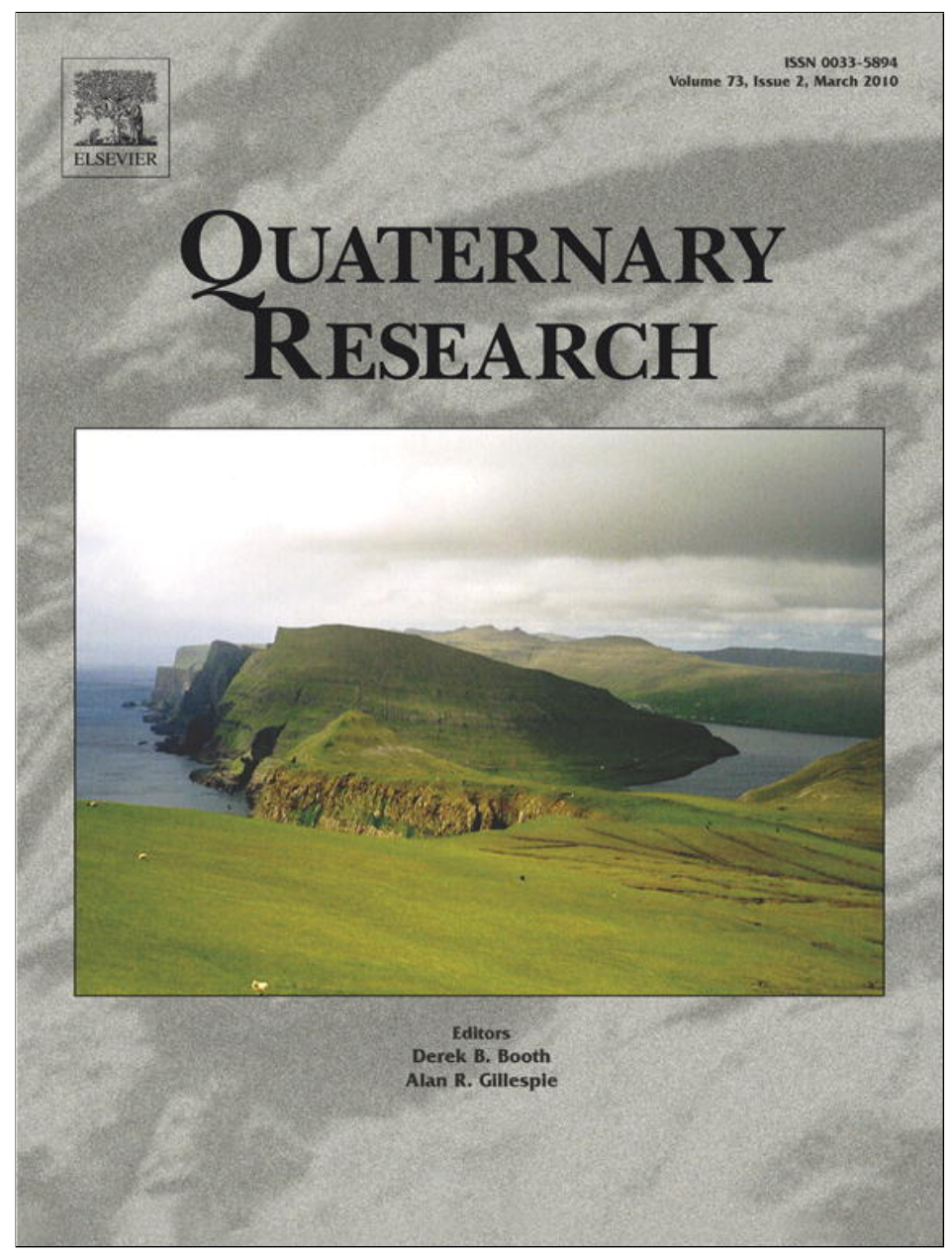

This article appeared in a journal published by Elsevier. The attached copy is furnished to the author for internal non-commercial research and education use, including for instruction at the authors institution and sharing with colleagues.

Other uses, including reproduction and distribution, or selling or licensing copies, or posting to personal, institutional or third party websites are prohibited.

In most cases authors are permitted to post their version of the article (e.g. in Word or Tex form) to their personal website or institutional repository. Authors requiring further information regarding Elsevier's archiving and manuscript policies are encouraged to visit:

http://www.elsevier.com/copyright 


\title{
Impact of earthquakes on agriculture during the Roman-Byzantine period from pollen records of the Dead Sea laminated sediment
}

\author{
Suzanne A.G. Leroy ${ }^{\mathrm{a}, *}$, Shmuel Marco ${ }^{\mathrm{b}}$, Revital Bookman ${ }^{\mathrm{c}}$, Charlotte S. Miller ${ }^{\mathrm{a}}$ \\ a Institute for the Environment, Brunel University, Uxbridge (West London) UB8 3PH, UK \\ ${ }^{\mathrm{b}}$ Department of Geophysics and Planetary Sciences, University of Tel-Aviv, Tel-Aviv 69978, Israel \\ ${ }^{c}$ Department of Marine Geosciences, University of Haifa, Haifa 31905, Israel
}

\section{A R T I C L E I N F O}

\section{Article history:}

Received 27 March 2009

Available online 24 November 2009

\section{Keywords:}

Dead Sea

Earthquake

Agriculture

Roman-Byzantine period

Seasonal lamination

Palynology

\begin{abstract}
A B S T R A C T
The Dead Sea region holds the archives of a complex relationship between an ever-changing nature and ancient civilisations. Regional pollen diagrams show a Roman-Byzantine period standing out in the recent millennia by its wetter climate that allowed intensive arboriculture. During that period, the Dead Sea formed laminites that display mostly a seasonal character. A multidisciplinary study focused on two earthquakes, 31 $\mathrm{BC}$ and $\mathrm{AD} 363$, recorded as seismites in the Ze'elim gully A unit III which has been well dated by radiocarbon in a previous study. The sampling of the sediment was done at an annual resolution starting from a few years before and finishing a decade after each earthquake. A clear drop in agricultural indicators (especially Olea and cereals) is shown. These pollen indicators mostly reflect human activities in the Judean Hills and coastal oases. Agriculture was disturbed in large part of the rift valley where earthquake damage affected irrigation and access to the fields. It took 4 to $5 \mathrm{yr}$ to resume agriculture to previous conditions. Earthquakes must be seen as contributors to factors damaging societies. If combined with other factors such as climatic aridification, disease epidemics and political upheaval, they may lead to civilisation collapse.
\end{abstract}

(C) 2009 University of Washington. Published by Elsevier Inc. All rights reserved.

\section{Introduction}

The Dead Sea region (Near East, Fig. 1) has been intensively studied for its complex and fascinating story of interaction between nature and past human societies. The region has been very dynamic over the recent millennia, both in terms of its natural (climatic fluctuations and geohazards) and societal modifications. The influence of environmental changes on humans has often been recognised as paramount. Drastic fluctuations of the Dead Sea (DS) water level have been measured (e.g., 28-m drop in the last century) and also reconstructed over the late Pleistocene and Holocene (Bookman et al., 2006). Over the last $2500 \mathrm{yr}$, repetitive shifts of vegetation belts along the relatively steep slopes of the rift valley occurred with changing precipitation (Enzel et al., 2003; Neumann et al., 2009b). Movements of the DS fault are suggested to have also had an influence on the course of history of this region (Ben-Avraham et al., 2005; Nur and Burgess, 2008). In the Middle East, during the transition from the Roman Empire to the Islamic period via the Byzantine period (63 BC$A D$ 638), a series of combined factors have rendered past societies fragile. These factors include, for example, climatic change, natural hazards, disease epidemics, and political and economical collapses leading to a deep crisis in the 6th century AD followed by a sharp decline in population in the following century (Hirschfeld, 2006).

\footnotetext{
* Corresponding author. Fax: +441895269 761.

E-mail address: suzanne.leroy@brunel.ac.uk (S.A.G. Leroy).
}

The potential role of earthquakes as a catalyst in the collapse of arboriculture at the end of the Byzantine period is examined in the DS region for an earlier period with mainly earthquake hazards. This allows isolating the effect of earthquakes from other damaging factors. Two seismites resulting from the earthquakes of $31 \mathrm{BC}$ and $\mathrm{AD}$ 363 and the following years of sedimentation are analysed for the first time at a seasonal resolution by palynology, geochemistry and magnetic susceptibility. Here, the negative impact of past earthquakes on agriculture and the duration of that impact are shown by palynology.

\section{Modern settings}

\section{Regional setting}

The Dead Sea is the lowest water body in the world (e.g., Niemi and Ben-Avraham, 1997), $423 \mathrm{~m}$ bsl in 2009. This water body is the Holocene surviving trace of a much larger late Pleistocene lake, Lake Lisan (Bookman et al., 2006). Until 1931 (when a dam on the outlet of Lake Kinneret was constructed), lake levels were changing according to rainfall on the watershed (approximately $43,000 \mathrm{~km}^{2}$ ). Now with the added withdrawal of water for agriculture, the level drop is ca. $1 \mathrm{~m}$ per year (e.g. Dayan and Morin, 2006). Anati et al. (1995) have analysed the evolution of the DS water column stratification over the period of 1977-1995. Until 1978, the DS was mostly meromictic. However, from February 1979, it became holomictic with a December 


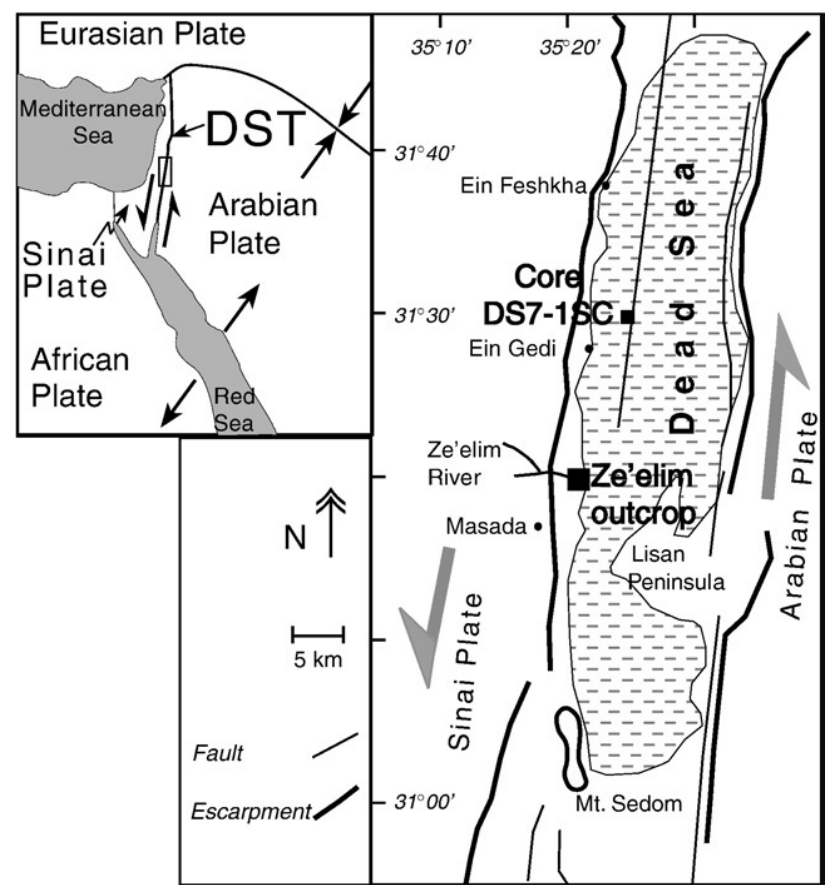

Figure 1. Location of the sites in the Dead Sea region. Insert: location of the Dead Sea in the Near East. DST, Dead Sea Transform Fault.

overturn and is only stratified and meromictic when there is a higher freshwater input due to either higher rainfall or a large release of water by the Degania dam (Gertman and Hecht, 2002). Moreover, a drastic change in the sedimentation in the DS took place in 1983 when the annual lamination was replaced by massive halite precipitation; this phenomenon therefore followed the first complete mixing by only a few years (Anati, 1993).

The average annual rainfall over the DS itself is $\sim 90 \mathrm{~mm}$, but most of the water entering the lake comes from a zone of relatively high rainfall in the upper Jordan River watershed, with an annual precipitation in excess of $600 \mathrm{~mm}$ (Dayan and Morin, 2006). Rain occurs between October and May, often with more rainfall at the transitional seasons (autumn and spring) and mostly in the form of rainstorms. The mean annual temperature east of Jerusalem (at Ma'ale Adumim, $330 \mathrm{~m}$ asl) is $19^{\circ} \mathrm{C}$, whereas near the DS's northern tip it rises to $23{ }^{\circ} \mathrm{C}$ (at Kalia, $60 \mathrm{~m} \mathrm{bsl}$ ) (Kutiel et al., 1995). Winds, a consequence of depressions during winter and spring, are mostly westerlies.

The main tributary to the DS is the Jordan River. A few perennial streams like Wadi el Mujib (Arnon) opposite Ein Gedi, discharge into the lake (El-Naqa 1993). Most of the wadis draining the hills are dry with the exception of winter floods from October to May. Springs such as Ein Feshkha, fed by aquifers from the Judean Mountains, emerge along the flanks of the DS (Ben-Itzhak and Gvirtzman, 2005).

\section{Vegetation}

The Dead Sea is surrounded by three altitudinal phytogeographic belts (Zohary and Orshansky, 1949; Rossignol, 1969). First, along the DS itself, the Saharo-Sindian (= Saharo-Arabic) vegetation (dry hamada dominated by Chenopodiaceae) reaches north up to $50 \mathrm{~km}$ from the DS, with rare enclaves of Sudano-Deccanian vegetation (with tropical elements such as Acacia) linked to freshwater springs. Higher up, Irano-Turanian vegetation is found on the slopes: a steppe with dwarf shrubs where Artemisia herba-alba then dominates. At higher elevations, the Mediterranean vegetation is developed to the west on the Judean hills ( $1020 \mathrm{~m}$ asl) and to the east on the Moab hills (1065 $\mathrm{m}$ ). The summits of these hills are more than $1400 \mathrm{~m}$ higher than the present DS level. Where the vegetation climax is reached, the semisteppe is then replaced by evergreen maquis with Quercus calliprinos (evergreen oak) and Juniperus. Neither oaks nor olive trees now grow in the DS trough.

Over the millennia, the cultivated surface has gone through periods of extension and contraction. During the Roman-Byzantine times (from $63 \mathrm{BC}$ to $\mathrm{AD}$ 638), large farmsteads and intensive production for exportation of olive oil, dates, opobasalm (an unspecified tree growing in Gilead) and spices have developed in addition to production for local use (Harland, 2002).

The strongly contrasted rainfall pattern is reflected by the period of flowering of many plants (Zohary and Orshansky, 1949). The vegetation around the DS therefore produces a pollen rain, which has a strong seasonal character (Feinbrun et al., 1959; Kantor et al., 1966; Horowitz 1979; Al-Eisawi and Dajani, 1988). This influences the pollen assemblages found in the sediment's sublaminae (Leroy, 2010). The strongest signal, however, remains the pollen concentration, which is high in autumn-winter-spring (dark laminae) when most plants bloom and low in summer (light laminae) when most plants are suffering from lack of humidity (Leroy, 2010).

\section{Ze'elim canyon and fan delta}

The Ze'elim sampling site is located on the southwestern shore of the present-day DS on a flat plain at an elevation of ca. $400 \mathrm{~m}$ bsl (Bookman et al., 2004). The Ze'elim River flows into the southern part of the DS north basin from the west and has a catchment area (250 $\mathrm{km}^{2}$ ) that is located mainly in the southern Judea desert. Presently, water flows through the canyon only several days a year, associated with storm events in the high-elevation Judea Desert (Magaritz et al., 1991). The Nahal Ze'elim delta is the largest of the active deltas located along the western margin of the depression. In terms of the morphometry of fan deltas worldwide, Nahal Ze'elim is relatively small $\left(\sim 6 \mathrm{~km}^{2}\right)$, its slope is steep $\left(2.5^{\circ}\right)$ and its catchment is quite large for the size of the sediment lobe (Warren, 2006).

\section{Past settings}

Past lake levels, climate and vegetation

One of the best records so far for sea level changes over the last $2500 \mathrm{yr}$ has been obtained from exposed sedimentary sequences along the western shores of the DS. The sea level change curve is based on identification of buried shoreline deposits within their sequences and their associated radiocarbon ages on organic debris (Enzel et al., 2003; Bookman et al., 2004, 2006). The Hellenistic and Byzantine high stand at $\geq 395 \mathrm{~m}$ bsl (ca. $250 \mathrm{BC}$ to AD 500) is interrupted by a brief low level at ca. AD 270 down to $404 \mathrm{~m}$ bsl. The final end of this high stand, however, comes after the $5^{\text {th }}$ century AD (Bookman et al., 2004, 2006).

Six pollen diagrams from sites along the west shore of the Dead Sea north and south basins have been compiled by Neumann et al. (2009b) in order to provide the history of vegetation change over the last $3500 \mathrm{yr}$. Reference will be made here especially to the deep-sea core taken offshore Ein Gedi (Heim et al., 1997; Leroy, 2010). Vegetation and agriculture changed roughly synchronously with lake levels, with the exception of the brief lake level drop around $\mathrm{AD}$ 270 , which is not well recorded in the six pollen diagrams so far.

\section{Lamination and earthquakes}

A large part of the Pleistocene sediment of the Lisan formation and most of the non-halite facies of the Holocene sediment of the Dead Sea are laminated. The usual, but not mandatory, succession of three facies in a year is the following: (1) clastics from river inflow in winter or runoff floods in the transition seasons (allochthonous origin), (2) 
gypsum and (3) aragonite, the last two by chemical precipitation (autochthonous origin) (Bentor and Vroman, 1960; Reid and Frostick, 1993; Migowski et al., 2004). More complicated laminations have been observed too: for example, light evaporitic ones with one or more thin detritic beds that could perhaps represent more than a year (Heim, 1998), or thick massive clastic units that may represent high frequency flashflood event(s) during relatively wet years.

The Dead Sea lies in a pull-apart basin within a continental transform plate boundary (Garfunkel, 1981; Niemi and Ben-Avraham, 1997). The distribution of earthquake epicentres suggests that the DS is one of the most active sections, north of Red Sea. Earthquakes caused by fault motion on the transform fault and associated structures have been felt throughout historical times. Several catalogues are available (e.g., Amiran et al., 1994; Guidoboni et al., 1994; Guidoboni et al., 2004) as well as surveys of earthquakedamaged structures (e.g., Reches and Hoexter, 1981; Ben-Menahem, 1991; Ellenblum et al., 1998; Zilbermann et al., 2005; Haynes et al., 2006; Thomas et al., 2007; Marco 2008).

Breccia layers composed of broken and mixed lacustrine seasonal laminae in the DS basin were interpreted as seismites (layers that exhibit earthquake-triggered deformation) (Marco and Agnon, 1995; Ken-Tor et al., 2001a; Agnon et al., 2006). The DS sediment in the Ze'elim gully is unique as it is extremely well dated owing to a detailed chronology and correlation of seismites to historical earthquakes (Fig. 2) (Ken-Tor et al., 2001a, 2001b). The organic debris used for dating comes from vegetation growing along streams and springs around the DS. Ken-Tor et al. (2001a) show a remarkable agreement between similar breccia layers, ages and historical earthquakes in the last $2000 \mathrm{yr}$ in the Ze'elim fan delta. Two seismites from this record were investigated in detail; seismite $\mathrm{B}$ correlated to the $31 \mathrm{BC}$ earthquake and seismite $\mathrm{D}$ correlated to the $\mathrm{AD} 363$ earthquake. These seismites were chosen for the following reasons. Both can be traced

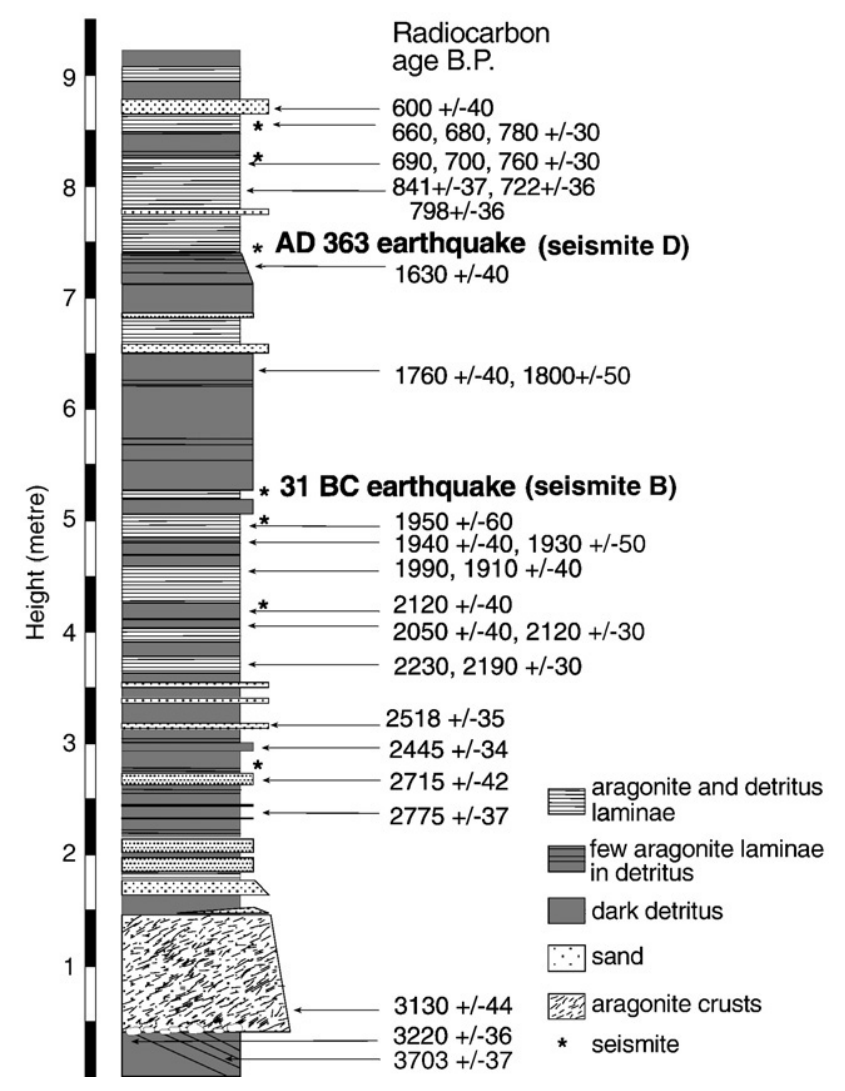

Figure. 2. The lithology and chronology of the section exposed at the Ze'elim site. Ages presented in ${ }^{14} \mathrm{C}$ yr BP. Marked are the seismites dated to the $31 \mathrm{BC}$ and AD 363 earthquakes. Calibrated dates of the seismites in Ken-Tor et al. (2001a, b). along the outcrops continuously and were dated previously in high accuracy. They were correlated to seismic events that left significant information in historical documentation and occurred during periods with relatively high population compared to following centuries.

For the two Roman-Byzantine earthquakes, physical characteristics followed by societal consequences are now briefly summarised. The earthquake of $31 \mathrm{BC}$ has been described by the contemporary historian, Josephus Flavius, in a very detailed account (Flavius, 1982). According to him, 30,000 persons were killed. There was severe damage in the DS area, Galilee and Judea. In Jerusalem, the earthquake damaged the second temple (see references in table 3 of Ken-Tor et al., 2001a). The earthquake caused confusion and fear. This paved the way for the expansion of the kingdom of Herod (Ben-Avraham et al., 2005). The earthquake was strong, with an estimated magnitude of 6.7 (Migowski et al., 2004, and reference therein) with an epicentre located on the main Jericho fault, north of the Dead Sea.

For the earthquake of $\mathrm{AD} 363$, reports are available from Baniyas in the north through to the Red Sea in the south and from the coastal littoral through the Jordan Valley and beyond (Thomas et al., 2007). In Jerusalem, the Temple area was damaged. A seiche was reported in the DS (see references in table 3 of Ken-Tor et al. 2001a). More specifically for the earthquake of AD 363, Russell (1980) suggested that major demographic shifts occurred in the Jewish populations of Galilee. Ken-Tor et al. (2001a) estimated that this was a strong earthquake whose epicentre was, however, not close to Ze'elim. This earthquake was part of an "earthquake storm," which may have caused the destructions of the middle 4th century AD when a series of significant earthquakes during a 30-yr period between AD 350 and 380 resulted in much damage at sites in Israel, Cyprus, NW Turkey, Crete, Corinth, Reggio Calabria, Sicily and northern Libya (Nur and Cline, 2000).

\section{Palynology and earthquakes}

Coseismic uplift or subsidence may alter vegetation formation, which in turn may be registered in pollen assemblages and concentrations within sediments (Mathewes and Clague, 1994; Mirecki, 1996). Exposure of new land has also been detected in pollen diagrams by the presence of pioneer plants (Cowan and McGlone, 1991). In the case of Lake Sapanca (NW Turkey), located on the North Anatolian Fault (Schwab et al., 2009; Leroy et al., 2009), palynology was used as a taphonomic indicator of changes in sedimentation type into the lake centre, especially sources (local vegetation versus altitudinal, shore versus deep lake) and accumulation rates (rapid inwash of pollen-depleted soils and river sediment following earthquakes). An assessment of the impact of earthquake activity on regional vegetation has been attempted in the Dead Sea's oasis of Ein Feshka (Neumann et al., 2009a). The investigation focused on blocks of sediment (including 1 to $3 \mathrm{yr}$ of sedimentation according to a laminite count) taken in three Holocene seismites and above them. The conclusions indicate that after the seismite in the Roman period there was no fluctuation. For the seismite at the Hellenistic to Roman transition, a weak signal is found in a decrease of Olea but not in the other cultivated plants. Finally, in the Byzantine period, a possible weak signal was found but only perhaps aggravating a trend started before the earthquake.

\section{Effects of earthquakes on vegetation and agriculture}

In the dry eastern Mediterranean region, earthquakes may damage the infrastructure necessary for agriculture, such as irrigation structures, and therefore cause a more or less long-lasting change in the pollen indicators of such activity. In the Near East, archaeological records show that ancient earthquakes have affected farm animals, water resources and agricultural infrastructure. In 31 BC, "an earthquake shock killed an infinite number of cattle" (Flavius, 
1982). After the AD 1202 earthquake, many sources mention abandonment of villages and deadly pestilence that affected livestock animals (Guidoboni et al., 1994). After the earthquake of AD 749, "the spring of water near Jericho was moved six miles from its place" (Michael the Syrian in Guidoboni et al., 1994). In the city of Sagalassos, Turkey, during the first half of the 6th century, an earthquake caused a lot of damage, amongst others destroying the aqueduct and causing severe water shortage to the town (Waelkens et al., 2000; SimiloxTohon et al., 2006). After reconstruction, a further earthquake in the 7th century may have been the cause of the final abandonment of the city. Water conduits in Iran, locally called "qanats," were also displaced by earthquakes, probably causing disruption in agricultural work (Ambraseys and Jackson, 1998). A 2000-yr-old aqueduct in Syria was found to have been repeatedly damaged by movements on the DS fault (Meghraoui et al., 2003). Haynes et al. (2006) described historical earthquake damage to a water reservoir and some aqueducts, one of them feeding an irrigation system in the archaeological site of Qasr Tilah in the Wadi Araba basin (Jordan).

Archaeological excavations at the site of Umm el Kanatir, east of the Sea of Galilee, revealed that the ancient village was abandoned after the AD 749 earthquake, which triggered a landslide that damaged most of the houses, the main water reservoir and the synagogue (Wechsler et al., 2008). The qanat system north of the Red Sea has been damaged by earthquakes on the Dead Sea Transform (Zilberman et al., 2005).

\section{Ze'elim canyon}

The Ze'elim canyon was already inhabited in the Neolithic period. Hirschfeld (2004) has proposed that the spring of Ein Aneva as known from hagiographical literature was located in the Ze'elim Wadi. Although this spring is now dry, it flowed abundantly in the Byzantine period. Byzantine terraces and a farmhouse indicate plentiful supplies of water. No signs of settlement were found dating of the period after the Byzantine one. In the oasis of Ein Gedi, a few kilometres to the north, irrigated agriculture with palm trees and barley was practised (Hadas, 2008). This collapsed in the middle of the 6th century.

\section{Material and methods}

\section{Subsampling of the outcrop of Ze'elim}

During our fieldwork in the Ze'elim fan, samples were taken in gully A unit III of Bookman et al. (2004) (Fig. 2). The same sampling location, however, does not exist anymore because the walls of the gullies erode very rapidly with each flash flood (Ben Moshe et al., 2008 ) in response to the drop of lake level. Two seismite layers, B and D, dated respectively to $31 \mathrm{BC}$ and AD 363, have been selected (KenTor et al., 2001a) (Fig. 2). An alternative age has been suggested for event D in Ein Gedi, AD 419 (Agnon et al. 2006), which is unlikely because fewer earthquake damages are known and based on a less likely chronology. These two seismites have been subsampled at a quasi-seasonal resolution by hand in the field directly from the gully wall (Fig. 3). The subsampling focused on the dark layers, i.e. autumn to spring, avoiding the white aragonitic and orange oxidised laminae in order to maximise the pollen concentration and to obtain in each sample most of the annual pollen influx. A few samples were taken in the seismite itself, representing a mix of the few years before the earthquake. Then, following the seismites, 9 to 10 consecutive samples were selected, representing most likely 9 to $10 \mathrm{yr}$ of sedimentation. The influx of pollen per $\mathrm{ml}$ per winter (roughly equivalent to year) is also in this present case taken as being identical to the annual pollen concentration.

\section{Radiocarbon dating}

The ages of the seismites were constrained by ${ }^{14} \mathrm{C}$ dates on organic debris derived from the deformed unit itself (seismite B) or by extrapolating between ages directly beneath and above the deformed unit (seismite D) (Ken-Tor et al., 2001a). The ${ }^{14}$ C ages were calibrated to calendar years defined by the $2 \sigma$ envelope error (Stuiver et al., 1998). The time elapsed between the deposition of the organic debris and the correlated historical earthquake was short relative to the uncertainty in the dating (Ken-Tor et al., 2001b).

\section{Palynological methods}

The samples were treated at the University of Bangor with the following sequence: pyrophosphate, $10 \% \mathrm{HCl}, 40 \%$ hot $\mathrm{HF}, 10 \% \mathrm{HCl}$ and sieving at 125 and $10 \mu \mathrm{m}$. The concentration in number of pollen grains and spores per ml of wet sediment was obtained with the initial addition of Lycopodium spore tablets. The counts reach a base sum of at least 600 grains per sample for the calculation of reliable percentages for the less abundant taxa. Outside of the base sum are the rare aquatic elements, the spores and the varia (unknown and indeterminable grains). Pollen diagrams are plotted using the program Psimpoll 2.27 (Bennett 2007). The pollen zones (pz) of the selected taxa diagrams are based on lithology and on a CONISS

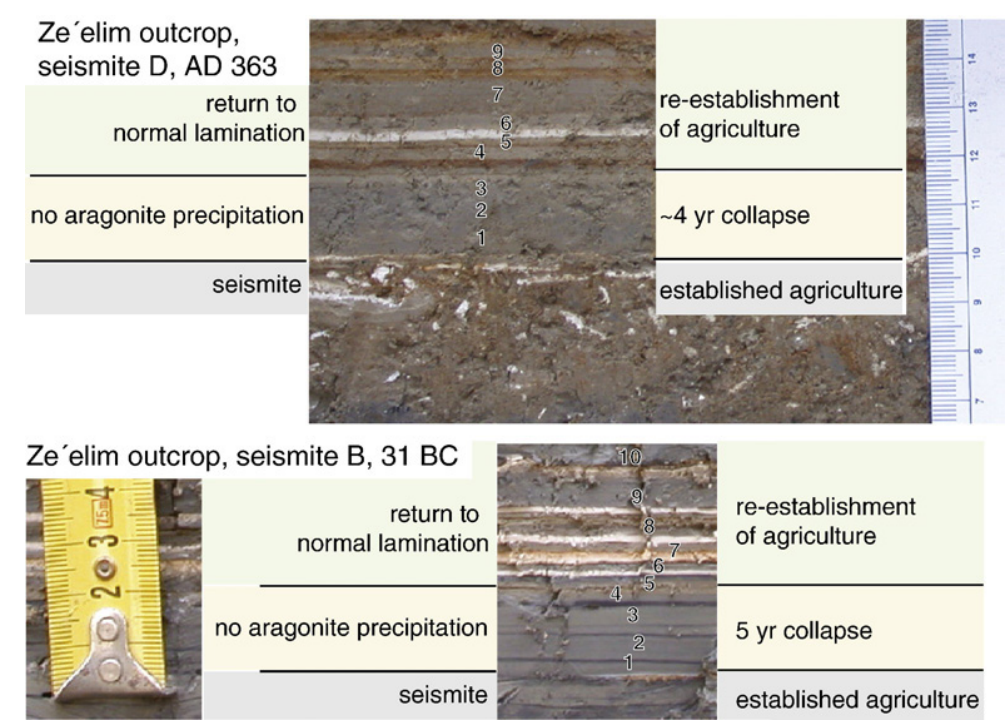

Figure 3. Photographs of the location of samples in the wall of gully A in and above the seismites of 31 BC and AD 363 in the Ze'elim site. 
analysis after square-root transformation. The detailed diagram of the two seismites is presented in the Supplementary material.

\section{Other methods}

Samples for geochemical analysis were taken at exactly the same levels as for the pollen analysis. The geochemistry data (10 oxides and two trace elements) were obtained at Gloucester University with inductively coupled plasma atomic emission spectroscopy (ICP-AES). Dried powder $(0.25 \mathrm{~g})$ mixed intimately with $0.75 \mathrm{~g}$ of lithium metaborate was fused at $1050{ }^{\circ} \mathrm{C}$ for $30 \mathrm{~min}$, then dissolved in $10 \%$ nitric acid and made up to volume to $250 \mathrm{ml}$ with distilled water. The ICP-AES data were calibrated against 10 international reference rock materials. The magnetic susceptibility was obtained by measurement by mass on the Bartington MS2 magnetometre. The dry samples were measured with the MS2B Dual Frequency Sensor for discrete samples. For a limited number of samples just after seismites B and D, mineralogy was tested by X-ray. At the Geological Survey of Israel, a Philips X-ray diffractometer (17130/1710) was operated with $40 \mathrm{kV}$ and $30 \mathrm{~mA}$, CuKa radiation, $1^{\circ}, 0.1 \mathrm{~mm}, 1^{\circ}$ slits and sealed proportional detector. The APD software controlled the running, calculated and printed peak locations and relative intensities, and controlled the diffractogram printout. Bulk mineralogical composition was determined by the highest reflections of each mineral.

\section{Results and interpretation}

\section{Laminite origins and duration estimates}

The field observation of the thickness and colour of lamination following seismites provide clues to the environmental changes caused by the earthquake events. After the 31 BC earthquake, alternating dark and light lamination did not return until $5 \mathrm{yr}$ afterwards. Instead of alternating dark detrital and aragonitic laminae, we observe four grey clay-rich layers separated by thin dark layers; whereas after the AD 363 earthquake, a visually massive deposition of $1.7 \mathrm{~cm}$ occurs that could have been deposited over several years (Fig. 3). The mineralogy of the first $\mathrm{cm}$ above seismite $\mathrm{D}$ is dominated by calcite, whereas above seismite B it is co-dominated by calcite and quartz. The secondary minerals were respectively quartz and clays or clays only. Minor traces of dolomite and aragonite were found. This conforms with a river inflow- or runoff-flood type of deposition.

Whereas the number of years after seismite $B$ is obtained by counting the number of black (or winter) layers, a field estimation for seismite D was taken as $3 \mathrm{yr}$, following on a common rule that an unclearly varved segment is equal to the average sedimentation rate of that above and below (Lotter, 1991). Moreover, for both seismites, a simple exercise has been done with the pollen concentration which should be roughly similar from year to year. If the massive deposition (divided in three adjoining samples of similar volumes in the field) is taken as formed in $1 \mathrm{yr}$ (by adding the concentration values of the three samples together), then the influx of pollen becomes extremely high (Fig. 4, top). If it is taken as forming in increasingly more years, the influx decreases. Finally, the best fit (alignment of the values with those earlier and later) is 4 yr for seismite $D$, suggesting one more year than the number of samples. For seismite B, the best fit is with $5 \mathrm{yr}$, confirming these laminites as yearly formed (Fig. 4, bottom).

The stable geochemical and magnetic susceptibility data indicate very little change in soil in-wash at the sampled locality (Figs. 5 and 6). Two samples after the $31 \mathrm{BC}$ seismite, however, contain a clear peak in both $\mathrm{Sr}$ and $\mathrm{Ba}$. This could reflect a brief and late (after 6 and 7 yr) influence of hydrothermal activity. The magnetic susceptibility indicates that in both cases the earthquakes had no effect on the values measured. There are, however, distinctively lower overall values for the seismite D samples than for the seismite B ones (Figs. 5 and 6).
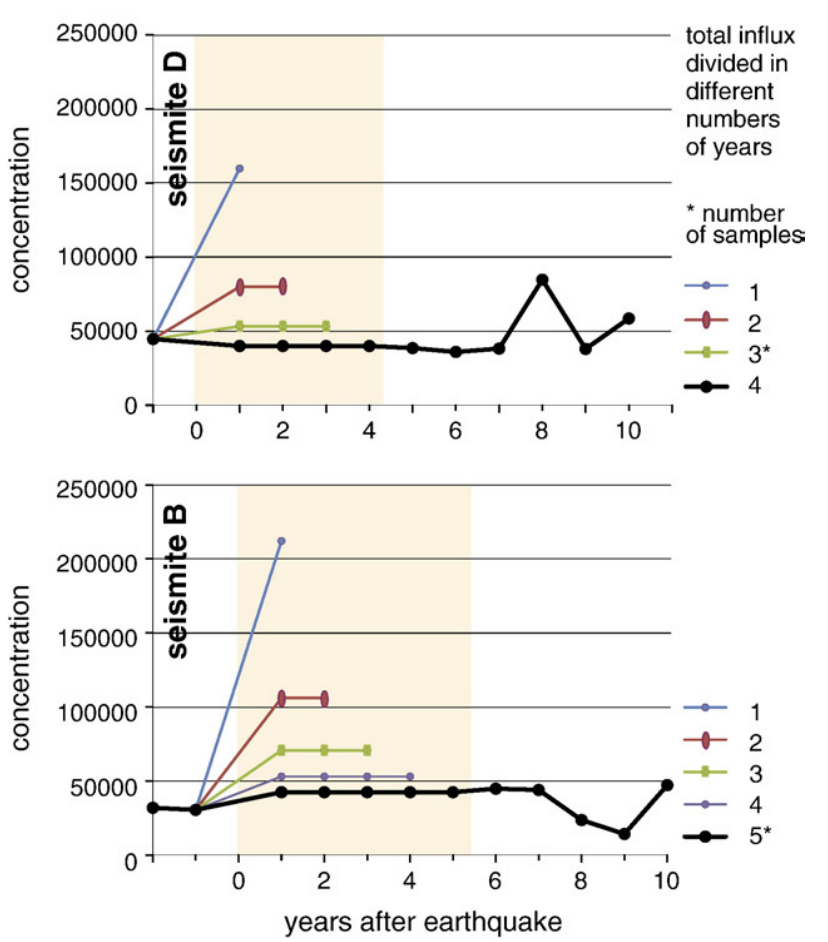

Figure 4. Various hypotheses for calculating pollen influx after each earthquake (pollen concentration in varying numbers of years after the earthquake). Bottom is seismite $B$; top is seismite D. The thick line represents the best hypothesis because of the stable influx.

The lack of clear variation in geochemistry and in the magnetic susceptibility indicates that the changes of pollen taxa percentages are not due to a different taphonomy such as a dilution of the lacustrine sediment by additional soil, nor to an accretion by unusual flash floods. The laminites just after the earthquakes therefore were probably deposited under the same processes than before the earthquake. Hence, the high-resolution pollen diagrams may be interpreted in terms of changes in vegetation cover rather than taphonomic change (Figs. 5 and 6).

\section{Interpretation of the pollen diagrams}

The pollen zonation closely follows the lithology in both seismites. In the $31 \mathrm{BC}$ diagram (seismite B), the pre-earthquake and postearthquake pollen assemblages ( $\mathrm{pz}$ ZB1 and 3) show signs of intense agriculture such as Cerealia-t. pollen grains and arboriculture with pollen of Olea (olive) and curve of other potentially cultivated trees/ bushes: Pistacia-Juglans-Vitis (pistachio, walnut and grape vine) (Fig. 5). However, the laminites following the earthquake ( $\mathrm{pz}$ ZB2) show a significant decline of human activities and an increase of desert plants (Amarantaceae-Chenopodiaceae) during the 5-yr interval. The olive groves would have produced less for a while (less blooming, fewer pollen grains) because of a temporary lack of management (ploughing and weeding of inter-tree soil, fertilisation and pruning) (Makhzoumi, 1997; Terral, 2000), whereas many cereal fields were not planted or suffered from the lack of maintenance of irrigation canals.

In the AD 363 diagram (seismite D), the vegetation (pz ZD1 and 3) is already clearly less modified by human activities than for the time of the 31 BC earthquakes: cereal fields are still there but the olive groves have been partially replaced by a wooded steppe and an open woodland (evergreen forest with oaks and pistachios with steppic elements such as Sarcopoterium (thorny burnet)), showing already in the area at that time a decline of human activities or a shift to other activities in that century (Fig. 6). About $4 \mathrm{yr}$ after the seismite (pz ZD2), a further temporary decline of human activities is nevertheless 


\section{Author's personal copy}

S.A.G. Leroy et al. / Quaternary Research 73 (2010) 191-200

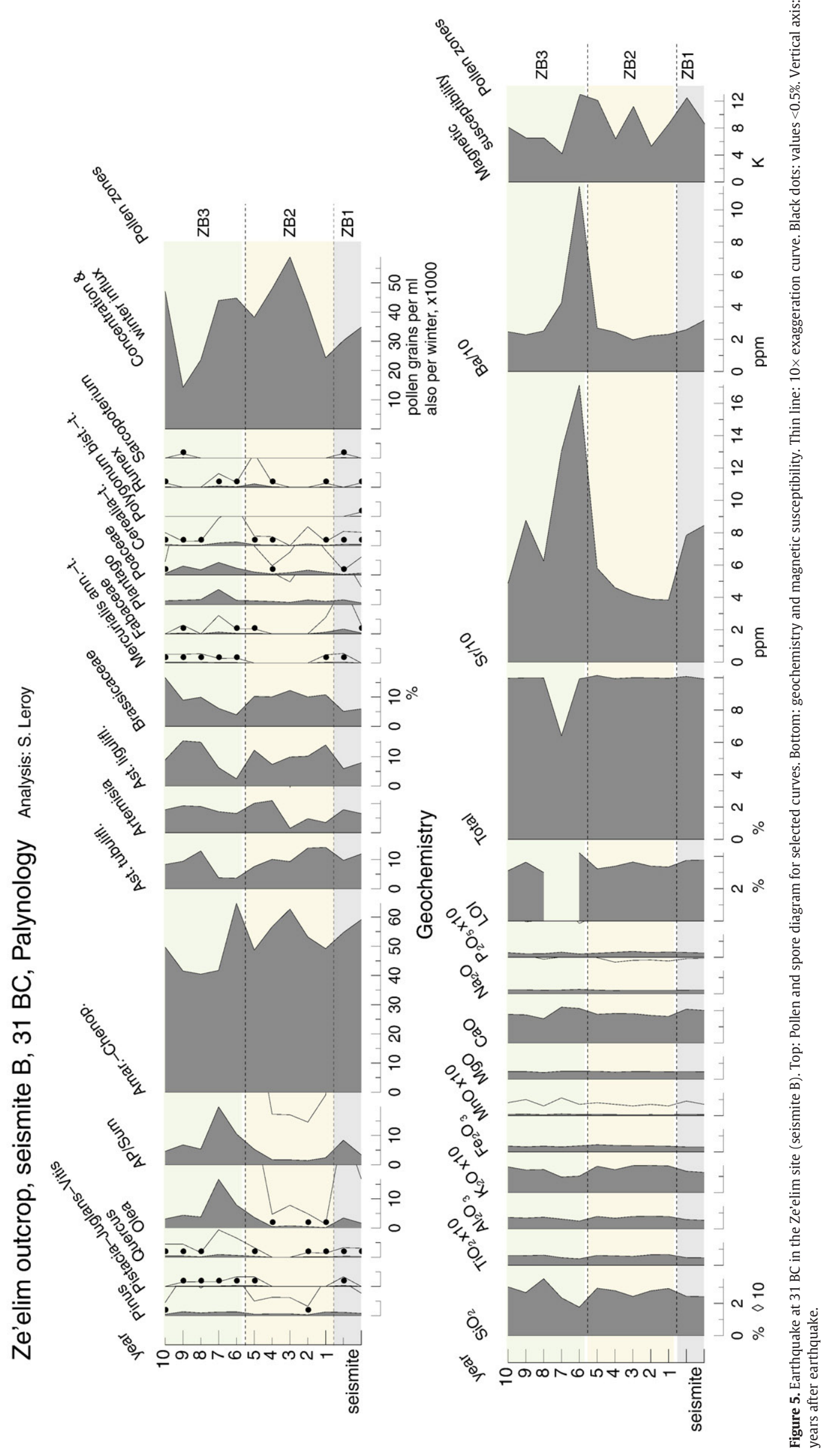




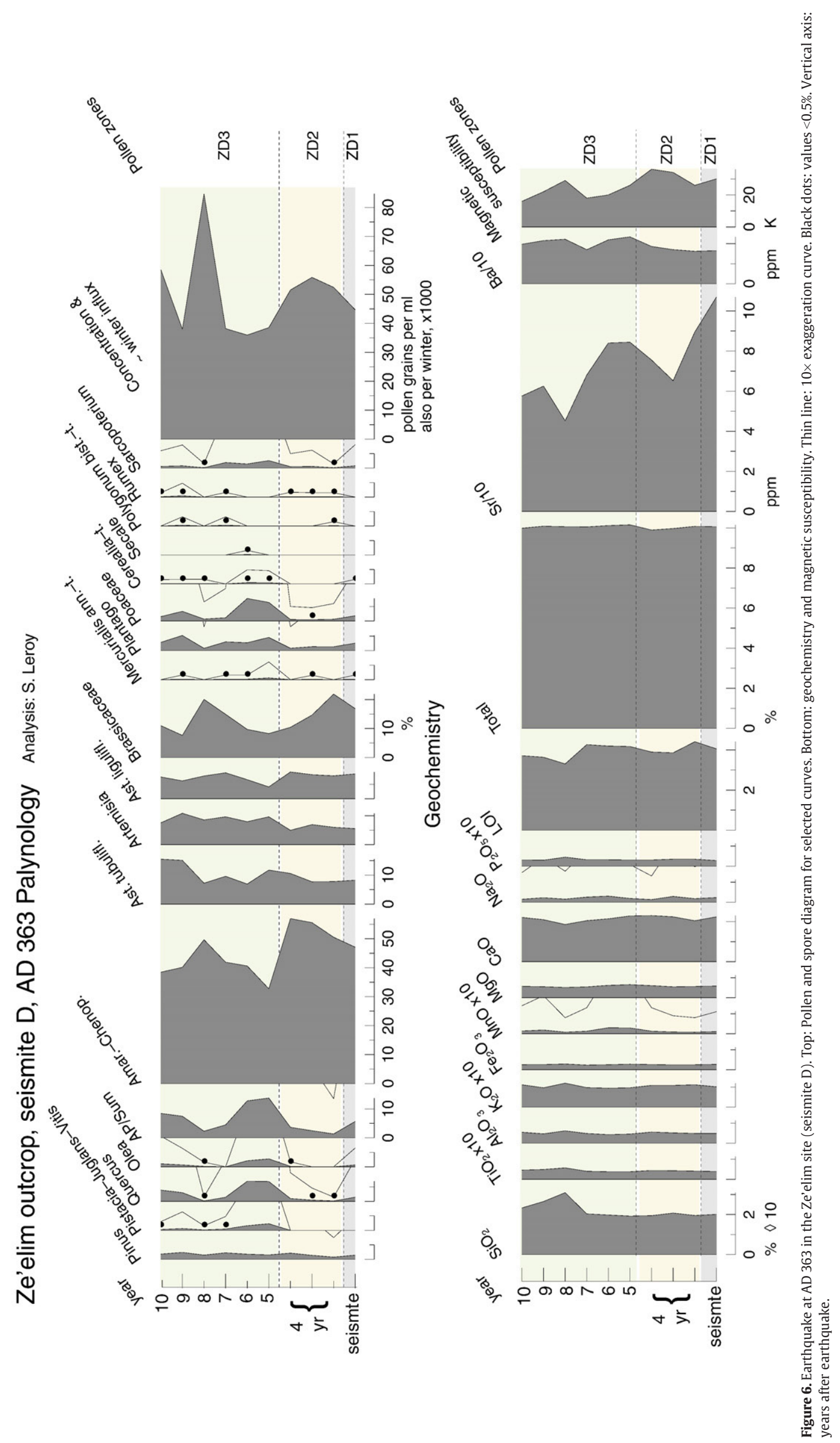


noticed: less Olea, less cereals and perhaps also less other cultivated trees/shrubs. The regional vegetation is affected with clearly more desertic/ruderal plants colonising the fallow lands.

\section{Discussion}

Other pollen analyses elsewhere in lake sequence with seismites show characteristic soil inwash or river inflow leading to widely different pollen concentrations. In Lake Sapanca (Turkey), pollen assemblages are different in turbidites and reworked horizons caused by earthquakes and, even more clearly, show much lower pollen concentrations due to dilution of the lake sediment by pollen-barren soils (Leroy et al., 2009). In other settings, it has been demonstrated that lakes with river inflow receive more pollen grains (higher influx) than lakes without rivers (Pennington, 1979). Therefore, here the atypical sediment above the seismites is most likely not attributable to single flood event(s) with an instantaneous duration(s). In conclusion, the impact of these earthquakes is estimated to have lasted for about 4-5 yr.

\section{Impact of earthquakes on DS agriculture and society}

The pollen spectra of the $31 \mathrm{BC}$ (seismite B) and the AD 363 (seismite D) earthquakes (Figs. 5 and 6) indicate that the two seismites most likely belong respectively to the beginning of pz DS2 (high Olea, some Juglans and Vitis) and to the end of pz DS2 (presence of Sarcopoterium and Pistacia but still low Pinus (pine) and reworked pollen) in core DS7-1SC (Leroy, 2010). The concentration values in the two seismite diagrams are much higher than those of the same period in core DS7-1SC (pz DS2 with only 6000 to 18,000 grains per ml; Leroy, 2010) and in the Ze'elim outcrop ZA-2 (Neumann et al., 2007). This is explained by the origin of pollen grains in a near-shore site, which is closer to plants and more affected by river sediment. In the ZA-2 pollen diagram (Neumann et al., 2007), seismite B is towards the beginning of the zone of maximal olive cultivation related to the Roman period (LPAZ 5), and seismite D is at the beginning of the increase of Pinus related to the transition from the Byzantine to the early Islamic period (LPAZ 6). Bookman et al. (2004) placed seismite B clearly in a period of high lake levels, whereas seismite $D$ is at it the end of one.

During the time of the two studied earthquakes, there were only isolated areas of agriculture along the shores of the Dead Sea. This was taking place in oases surrounded by desert. Hirschfeld (2004) described farmhouses, terraces and vegetable gardens in Ein Aneva and Ein Gedi. Archaeological digging in Ein Gedi showed barley growing (Hordeum vulgare) in irrigated fields but the clear absence of olive trees (Hadas, 2008). Moreover, it is likely that owing to the higher rainfall of that period, the boundaries between the Mediterranean vegetation, the steppe and the desert would have shifted southwards and downwards. More land was devoted to agriculture than nowadays and a larger portion of land with olive groves (Leroy, 2010).

The length of the impact on agriculture on local society implies that people had to move away temporarily and that agriculture was deeply disrupted both in the oases along the coast and higher on the slopes of the rift valley (the two main sources of pollen indicators of human activities). The lack of maintenance decreased the production of the Olea trees. The Olea biennial alternation of pollen production cannot be the cause as the observed changes are $>2 \mathrm{yr}$ (FernandezMensaque et al., 1998). More decisively for the cereals, the disruption of irrigation and the absence of people would have stopped plantation in the fields. It is also not impossible that the earthquake caused a drop of the level of the water table and a modification (decrease?) of the spring flow. In 31 BC, Palestine was under the reign of King Herod. This was a relatively stable period; although in that year, Herod won a battle against the Nabateans but after a brief war only (about one year long). The 4th century AD Palestine knew a period of political stability (Hirschfeld, 2004). It was then still under Roman rule. Therefore, it is not unlikely that rural life was restored quickly, perhaps more easily than after the $31 \mathrm{BC}$ earthquake.

The AD 363 earthquake was followed in the succeeding centuries by a period with an accumulation of damaging factors to the society. There was not only a progressive aridification of climate (falling DS levels) from AD 550 onwards, a radical change in modes of food production (agriculture to pastoralism) in the late 6th and early 7th centuries, deep social/religious changes, the Justinian plague in AD 541 and invasions into the Roman Empire, but also an earthquake storm causing devastation to a large part of the east Mediterranean world in the 4th to 6th centuries (Stiros, 2001; Hirschfeld, 2006). Under those conditions, past societies may have suffered from a "ratchet effect" of vulnerability. This occurs when each succeeding event reduces the resources that a group, or individual, has to resist and recover before the next environmental shock or stress (Ford et al., 2006). In extreme cases, it may lead to societal collapse (Leroy, 2006). Earthquakes must be seen as part of a larger ensemble of hazards that affected the population leading to collapse at or close to the transition between the Byzantine period and the Islamic period, a time of the dramatic decrease of agriculture in the DS basin and its surroundings (Hirschfeld, 2006; Neumann et al., 2009b; Leroy, 2010).

\section{Conclusions}

The impact of earthquakes on the environment is studied for the first time at an exceptionally high time resolution for most proxies (e.g., magnetic susceptibility). In the sedimentary record of Ze'elim (Dead Sea), the influence of two earthquakes (31 BC and AD 363) on agriculture has been shown to last 5 and $\sim 4 \mathrm{yr}$, respectively, which was a disaster for the sparse local settlements on the western shores (e.g., the oases of Ein Aneva, Ein Gedi and Ein Feshkha) and the marginal agriculture on the western rift slopes. The drastic reduction in agriculture for a few years in the DS rift (and probably in other regions affected by the earthquakes) is not sufficient, however, to cause a civilisation collapse unless it takes place in combination with other damaging factors over larger areas such as aridification of the climate, political instability, population displacements and plagues (Hirschfeld, 2006; Leroy, 2006). This combination of factors may, however, have taken place a few centuries later at the end of the Byzantine period.

\section{Acknowledgments}

The first author is grateful to the Isaiah Berlin Israel Travel Award (UK) for flight funding to Israel and to the British Academy (UK), grant SG-37303, for fieldwork funding in Ze'elim and the pollen and geochemical analyses of the Ze'elim samples. Dr. Amir Sandler graciously ran three X-ray samples at the Geological Survey of Israel. M. Turner (Brunel University) kindly revised the English of an earlier manuscript draft.

\section{Appendix A. Supplementary data}

Supplementary data associated with this article can be found, in the online version, at doi:10.1016/j.yqres.2009.10.003.

\section{References}

Agnon, A., Migowski, C., Marco, S, 2006. Intraclast breccias in laminated sequences reviewed: recorders of paleo-earthquakes. In: Enzel, Y., Agnon, A., Stein, M. (Eds.), New Frontiers in Dead Sea Paleoenvironmental Research. Geological Society of America Special Publication, pp. 195-214.

Al-Eisawi, D., Dajani, B., 1988. Airborne pollen of Jordan. Grana 27, 219-227. 
Ambraseys, N.N., Jackson, J.A., 1998. Faulting associated with historical and recent earthquakes in the Eastern Mediterranean region. Geophysical Journal International 133, 390-406

Amiran, D.H.K., Arieh, E., Turcotte, T., 1994. Earthquakes in Israel and adjacent areas: macrosesismic observations sine 100 BCE. Israel Exploration Journal 44, 260-305.

Anati, D., 1993. How much salt precipitates from the brines of a hypersaline lake? The Dead Sea as a case study. Geochimica et Cosmochimica Acta 57, 2191-2196.

Anati, D.A., Gavrieli, I., Oren, A., 1995. The residual effect of the 1991-93 rainy winters on the Dead Sea stratification. Israel Journal of Earth Sciences 44, 63-70.

Ben-Avraham, Z., Lazar, M., Schattner, U., Marco, S., 2005. The Dead Sea Fault and its effect on civilization. In: Wenzel, F. (Ed.), Perspectives in Modern Seismology. Lecture Notes in Earth Sciences 105, Springer Verlag Heidelberg, pp. 147-170.

Ben-Itzhak, L., Gvirtzman, H., 2005. Groundwater flow along and across structural folding: an example from the Judean Desert. Israel Journal of Hydrology 312, 51-69.

Ben-Menahem, A., 1991. Four thousand years of seismicity along the Dead Sea rift. Journal of Geophysical Research 96, B12 20,195-20,216

Ben Moshe, L., Haviv, I., Enzel, Y., Zilberman, E., Matmon, A., 2008. Incision of alluvial channels in response to a continuous base level fall: field characterization, modeling, and validation along the Dead Sea. Geomorphology 93, 524-536.

Bennett, K., 2007. Documentation for Psimpoll and Pscomb. http:// www.chrono.qub. ac.uk/psimpoll/psimpoll.html, accessed on 9 Feb. 2009

Bentor, Y.K., Vroman, A., 1960. The geological map of Israel, 1:100,000. Sheet 16, Mt. Sedom: Jerusalem. Geological Survey of Israel, p. 117.

Bookman (Ken-Tor), R., Enzel, Y., Agnon, A., Stein, M., 2004. Late Holocene lake levels of the Dead Sea. Geological Society American Bulletin 116 (5/6), 555.

Bookman, R., Bartov, Y., Enzel, Y., Stein, M., 2006. Quaternary lake levels in the Dead Sea basin: two centuries of research. In: Enzel, Y., Agnon, A., Stein, M. (Eds.), New Frontiers in Dead Sea Paleoenvironmental Research. Geological Society of America, Special paper 401, pp. 155-170.

Cowan, H.A., McGlone, M.S., 1991. Late Holocene displacements and characteristic earthquakes on the Hope River segment of the Hope Fault, New Zealand. Journal Royal Society New Zealand 21, 373-384.

Dayan, U., Morin, E., 2006. Flash flood-producing rainstorms over the Dead Sea, Israel: a review. In: Enzel, Y., Agnon, A., Stein, M. (Eds.), New Frontiers in Dead Sea Paleoenvironmental Research. Geological Society of America, Special Paper 401, pp. $53-62$.

Ellenblum, R., Marco, S., Agnon, A., Rockwell, T., Boas, A., 1998. Crusader castle torn apart by earthquake at dawn, 20 May 1202. Geology 26, 303-306.

El-Naqa, A., 1993. Hydrological and hydrogeological characteristics of Wadi el Mujib catchment area. Jordan. Environmental Geology 22, 257-271.

Enzel, Y., Bookman (Ken-Tor), R., Sharon, D., Gvirtzmann, H., Dayan, U., Ziv, B., Stein, M., 2003. Late Holocene climates of the Near East deduced from Dead Sea level variations and modern regional winter rainfall. Quaternary Research 60, 263-273.

Feinbrun, N., Rahat, A., Tas, J., 1959. Further studies in atmospheric pollen in Jerusalem. Bulletin Research Council 8D, 31-40.

Fernandez-Mensaque, P.C., González Minero, F.J., Morales, J., Tomas, C., 1998. Forecasting olive (Olea europaea) crop production by monitoring airborne pollen. Aerobiologia 14, 185-190.

Flavius, J., 1982. The Jewish War. Zondervan, Grand Rapids, Michigan.

Ford, J.D., Smit, B., Wandel, J., 2006. Vulnerability to climate change in the Arctic: a case study from Arctic Bay, Canada. Global Environmental Change 16, 145-160.

Garfunkel, Z., 1981. Internal structure of the Dead Sea leaky transform (rift) in relation to plate kinematics. Tectonophysics $80,81-108$.

Gertman, I, Hecht, A., 2002. The Dead Sea hydrography from 1992 to 2000. Journal of Marine Systems 35, 169-181.

Guidoboni, E., Bernardini, F., Comastri, A., 2004. The 1138-1139 and 1156-1159 destructive seismic crises in Syria, south-eastern Turkey and northern Lebanon. Journal of Seismology 8, 105-127.

Guidoboni, E., Comastri, A., Traina, G., 1994. Catalogue of Ancient Earthquakes in the Mediterranean Area Up to the 10th Century. Istituto Nazionale di Geofisica, Bologna.

Hadas, G., 2008. Irrigation agriculture in the oasis of Ein Gedi, Israel, and its parallels in oases around the Dead Sea in the Roman and Byzantine periods. In: Hermon, E. (Ed.), L'eau comme patrimoine. Les presses de l'Université de Laval, pp. 413-428.

Harland, P.A., 2002. The economy of first century Palestine: the state of scholarly discussion. In: Blasi, A.J., Turcotte, P.-A., Duhaime, J. (Eds.), Handbook of Early Christianity: Social Science Approaches. Alta Mira Press, Walnut Creek, CA, pp. 511-527.

Haynes, J., Niemi, T.M., Atallah, M., 2006. Evidence for ground-rupturing earthquakes on the Northern Wadi Araba fault at the archaeological site of Qasr Tilah, Dead Sea transform fault system, Jordan. Journal of Seismology 10, 415-430.

Heim, C., 1998. Holozäne Sedimente aus dem Toten Meer als Paläoklima-Indikatoren. Scientific Technical Reports, GeoForschungsZentrum Potsdam 98/12.

Heim, C., Nowaczyk, N., Negendank, J., Leroy, S.A.G., Ben-Avraham, Z., 1997. Middle-East desertification: evidence from the Dead Sea. Naturwissenschaften 84, 398-401.

Hirschfeld, Y., 2004. A climatic change in the early Byzantine period? Some archaeological evidence. Palestine Exploration Quarterly 136 (2), 133-149.

Hirschfeld, Y., 2006. The crisis of the sixth century: climatic change, natural disasters and the plague. Mediterranean Archaeology and Archaeometry 6, 19-32.

Horowitz, A., 1979. The Quaternary of Israel. Academic Press, New York.

Kantor, Z., Frank, M., Hoch-Kantor, D., Barkai-Golan, R., Marian, D., Schachnner, E., Kessler, A., de Vries, A., 1966. Airborne allergens and clinical response of asthmatics in Arad, a new town in a desert area in Israel. Journal of Allergy 37 (2), 65-74.
Ken-Tor, R., Enzel, Y., Stein, M., Marco, S., Negendank, J., 2001a. High-resolution geological record of historic earthquakes in the Dead Sea basin. Journal of Geophysical Research 106 (B2), 2221-2234.

Ken-Tor, R., Stein, M., Enzel, Y., Agnon, A., Marco, S., Negendank, J.F.W., 2001b. Precision of calibrated radiocarbon ages of historic earthquakes in the Dead Sea basin. Radiocarbon 43 (3), 1371-1382.

Kutiel, P., Lavee, H., Shoshany, M., 1995. Influence of a climatic gradient upon vegetation dynamics along a Mediterranean-arid transect. Journal of Biogeography 22, $1065-1071$.

Leroy, S.A.G., 2006. From natural hazard to environmental catastrophe, past and present. Quaternary International 158, 4-12.

Leroy, S.A.G., 2010. Pollen analysis of core DS7-1SC (Dead Sea) showing intertwined effects of climatic change and human activities in the Late Holocene. Journal of Archaeological Science 37 (2), 306-316

Leroy, S.A.G., Boyraz, S., Gürbüz, A., 2009. High-resolution palynological analysis in Lake Sapanca as a tool to detect earthquakes on the North Anatolian Fault over the last 55 years. Quaternary Science Reviews 28, 2616-2632.

Lotter, A.F., 1991. Absolute dating of the late-glacial period in Switzerland using annually laminated sediments. Quaternary Research 35, 321-330.

Magaritz, M., Rahner, S., Yechieli, Y., Krishnamurthy, R.V., $1991 .{ }^{13} \mathrm{C} /{ }^{12} \mathrm{C}$ ratio in organic matter from the Dead Sea area: paleoclimatic interpretation. Naturwissenschaften $78,453-455$.

Makhzoumi, J.M., 1997. The changing role of rural landscapes: olive and carob multiuse tree plantations in the semi-arid Mediterranean. Landscape and Urban Planning 37, 115-122.

Marco, S., 2008. Recognition of earthquake-related damage in archaeological sites: Examples from the Dead Sea fault zone. Tectonophysics 453, 148-156.

Marco, S., Agnon, A., 1995. Prehistoric earthquake deformations near Masada, Dead Sea graben. Geology 23 (8), 695-698.

Mathewes, R.W., Clague, J.J., 1994. Detection of large prehistoric earthquakes in the Pacific Northwest by microfossil analysis. Science 264, 688-691.

Meghraoui, M., Gomez, F., Sbeinati, R., Van der Woerd, J., Mouty, M., Nasser, A., Darkal Radwan, Y., Layyous, I., Al Najjar, H., Darawcheh, R., Hijazi, F., AlGhazzi, R., Barazangi, M., 2003. Evidence for 830 years of seismic quiescence from palaeoseismology, archaeoseismology and historical seismicity along the Dead Sea fault in Syria. Earth and Planetary Science Letters 210, 35-52.

Migowski, C., Agnon, A., Bookman, R., Negendank, J.F.W., Stein, M., 2004. Recurrence pattern of Holocene earthquakes along the Dead Sea Transform revealed by varvecounting and radiocarbon dating of lacustrine sediments. Earth and Planetary Science Letters 222, 301-314.

Mirecki, J.E., 1996. Recognition of the 1811-1812 New Madrid earthquakes in Reelfoot Lake, Tennessee sediments using pollen data. Journal of Paleolimnology 15, 183-191.

Neumann, F.H., Kagan, E.J., Schwab, M.J., Stein, M., 2007. Palynology, sedimentology and palaeoecology of the late Holocene Dead Sea. Quaternary Science Reviews 26, $1476-1498$

Neumann, F.H., Kagan, E.J., Stein, M., Agnon, A., 2009a. Assessment of the effect of earthquake activity on regional vegetation-high-resolution pollen study of the Ein Feshka section, Holocene Dead Sea. Review of Palaeobotany and Palynology online.

Neumann, F.H., Kagan, E.J., Leroy, S.A.G., Baruch, U., 2009b. Vegetation history and climate fluctuations on a transect along the Dead Sea west shore and their impact on past societies over the last 3500 years. Journal of Arid Environments.

Niemi, T.M., Ben-Avraham, Z., 1997. Active tectonics in the Dead Sea Basin. In: Niemi, T. M., Ben-Avraham, Z., Gat, J. (Eds.), The Dead Sea: The Lake and Its Settings. Oxford University Press, New York, pp. 73-81.

Nur, A., Burgess, D., 2008. Apocalypse: Earthquakes, Archaeology and the Wrath of God. Princeton University Press.

Nur, A., Cline, E.H., 2000. Poseidon's horses: plate tectonics and earthquake storms in the Late Bronze Age Aegean and Eastern Mediterranean. Journal of Archaeological Science 27, 43-63.

Pennington, W., 1979. The origin of pollen in lake sediments: an enclosed lake compared with one receiving inflow streams. New Phytologist 83, 189-213.

Reches, Z., Hoexter, D.F., 1981. Holocenic seismic and tectonic activity in the Dead Sea area. Tectonophysics $80,235-254$.

Reid, I., Frostick, L., 1993. Late Pleistocene rhythmite sedimentation at the margin of the Dead Sea Trough: a guide to palaeoflood frequency. In: McManus, J., Duck, R. (Eds.), Geomorphology and Sedimentology of Lakes and Reservoirs. J. Wiley and sons, pp. 259-273.

Rossignol, M., 1969. Sédimentation pollinique récente dans la Mer Morte. Pollen et Spores 9, 17-38.

Russell, K., 1980. The earthquake of May 19, AD 363. Bulletin American School Oriental Research 28, 47-64.

Schwab, M.J., Werner, P., Dulski, P., McGee, E., Nowaczyk, N., Bertrand, S., Leroy, S.A.G., 2009. Palaeolimnology of Lake Sapanca and identification of historic earthquake signals, Northern Anatolian Fault Zone (Turkey). Quaternary Science Reviews 28, 991-1005.

Similox-Tohon, D., Sintubin, M., Muchez, Ph., Verhaert, G., Vanneste, K., Fernandez, M., Vandycke, S., Vanhaverbeke, H., Waelkens, M., 2006. The identification of an active fault by a multidisciplinary study at the archaeological site of Sagalassos (SW Turkey). Tectonophysics 420, 371-387.

Stiros, S.C., 2001. The AD 365 Crete earthquake and possible seismic clustering during the fourth to sixth centuries AD in the Eastern Mediterranean: a review of historical and archaeological data. Journal of Structural Geology 23, 545-562.

Stuiver, M., Reimer, P.J., Bard, E., Beck, J.W., Burr, G.S., Hughen, K.A., Kromer, B., McCormac, G., van der Plicht, J., Spurk, M., 1998. INTCAL98 radiocarbon age calibration, 24,000-0 cal BP. Radiocarbon 40 (3), 1041-1083. 
Terral, J.-F., 2000. Exploitation and management of the olive tree during prehistoric times in the Mediterranean France and Spain. Journal of Archaeological Science 27, 127-133.

Thomas, R., Niemi, T.M., Parker, S.T., 2007. Structural damage from earthquakes in the 2nd-9th Century at the archaeological site of Aila in Aqaba, Jordan. Bulletin of the American School of Oriental Research 346, 59-77.

Waelkens, M., Sintubin, M., Muchez, Ph., Paulissen, E., 2000. Archaeological, geomorphological and geological evidence for a major earthquake at Sagalassos (SW Turkey) around the middle of the seventh century AD. In: McGuire, B. Griffiths, D., Stewart, I. (Eds.), The Archaeology of Geological Catastrophes. Geological Society, London, Special Publications, 171, pp. 373-383.
Warren, J.K., 2006. Evaporites: Sediments, Resources and Hydrocarbons. Springer Verlag, Berlin, Heidelberg, New York.

Wechsler, N., Katz, O., Dray, Y., Gonen, I., Marco, S., 2008. Estimating location and size of historical earthquake by combining archaeology and geology in Um-El-Kanatir Dead Sea Transform. Natural Hazards accepted.

Zilberman, E., Amit, R., Porat, N., Enzel, Y., Avner, U., 2005. Surface ruptures induced by the devastating $1068 \mathrm{AD}$ earthquake in the southern Arava valley, Dead Sea Rift, Israel. Tectonophysics 408, 79-99.

Zohary, M., Orshansky, G., 1949. Structure and ecology of the vegetation in the Dead Sea region of Palestine. Journal of Botany 4, 177-206. 